\title{
Diversity and Species Composition of Odonates (Insecta: Odonata) of Hutan Lipur Soga Perdana, Batu Pahat, Johor, Malaysia: A Green Lung
}

\author{
Muhamad Amirul Ashraf Abdul Aziz and Maryati Mohamed*
}

Centre of Research for Sustainable Uses of Natural Resources, Faculty of Applied Sciences and Technology, Universiti Tun Hussein Onn Malaysia, Bandar Universiti, 84500, Pagoh, Johor, Malaysia.

Received 30 September 2017; accepted 1 Februari 2018; available online 1 August 2018

DOI: https://10.30880/jst.2018.10.02.001

\begin{abstract}
In Malaysia, Odonates have been used widely in the assessment of water quality. This study is part of an effort to prepare a baseline data for the state of Johor, where development is happening at a fast rate which in turn could affect the water quality. Hutan Lipur Bukit Soga Perdana is a green lung for Batu Pahat which is considered as the second largest industrial town in Malaysia. Opportunistic sampling using sweep nets along $1 \mathrm{~km}$ line transect was conducted for a total of six days. Twenty-two species of Odonata belonging to 17 genera and seven families were recorded. Among the seven families, the most species-rich were Libellulidae (12 species) followed by Coenagrionidae and Platycnemididae (three species) while Gomphidae, Platystictidae, Devadattidae and Euphaeidae represented by single species. Drepanosticta fontinalis, a damselfly endemic to Peninsular Malaysia was collected. The abundance of the endemic Drepanosticta fontinalis was $10.3 \%$ from a total of 126 individuals. Tyriobapta torrida (15.9\%) was found to be the most abundant species found followed by Prodasineura notostigma $(12.7 \%)$ and Neurothemis fluctuans (11.9\%). The data were further analysed by using Shannon-Wiener Species Diversity Index giving a value of 2.63 indicating a moderate diversity. Simpson's Evenness is 0.91 indicating a high evenness in the distribution of Odonates. Since the forest gains high public interest in Batu Pahat and Odonates are visible and useful insects, more studies could be done, and the data could be transferred to the public as a model for biodiversity and conservation.
\end{abstract}

Keyword: Odonata, Dragonflies, Damselflies, Green lung, Green spaces, Hutan Lipur Soga Perdana, Batu Pahat, Johor, Malaysia.

\section{Introduction}

Batu Pahat is the 16th largest urban area in Malaysia by 2012 in terms of population with over 300,000 and known as "Northern Johor Shopping Paradise" due to the rapid development of shopping malls and hypermarkets [1]. Hutan Lipur Soga Perdana is a green lung for Batu Pahat located $5 \mathrm{~km}$ from the nearest town of Batu Pahat through Jalan Kluang-Batu Pahat. HLSP (N 01 ${ }^{\circ} 50^{\prime} .899^{\prime}$ ' E $\left.102^{\circ} 57^{\prime} .627^{\prime \prime}\right)$ is part of Soga Forest Reserve which is a highland dipterocarp forest with rich diversity of flora and fauna. HLSP is an ideal destination for relaxation and recreational activity such as hiking and jungle trekking.

A total of 5680 species of odonates has been described worldwide including 2739 species belonging to Zygoptera (damselflies) and the remaining 2941 species belonging to Anisoptera (dragonflies) [2]. As reported in [3], 342 species of odonates were recorded in Malaysia which includes 239 species recorded from Sabah, Sarawak, and Brunei while 235 named species from Peninsular Malaysia including Singapore and these number has been increased to over 250 with discoveries of new species $[4,5]$.

High diversity of flora and fauna within the protected areas are the key reasons for conservation and continuous monitoring is needed for ecosystem management and conservation purposes [6] as the conservation of biodiversity and management are of a worldwide concern [7]. Most species of odonates are restricted to specific habitats and the main concern is the stenotopic species $[8,9]$. The main factor that determines the distribution pattern of odonates is an ideal habitat in order to maintain their population as they utilizes a wide range of aquatic habitats [10].

The highest diversity of odonates were recorded in the tropics due to the environmental factor that is ideal for their population [11]. The tropical rainforests contain the highest diversity of odonates [12] and this is supported by research stating that the running waters in tropical rainforest 
support the greatest diversity of odonates across the world [2]. Tropical rainforest have a variety of aquatic habitats that are favorable for odonate population [13].

This report describes the results from the collection of odonates carried out at HLSP during two surveys on December 2016 and January 2017 for a total of six days of sampling and presents as an inventory of the odonate known from the site and provide the baseline data for Johor, Malaysia. The outcome of the report can assist the management of protected areas and provide the first step towards odonate conservation in Malaysia.

\section{Materials and Methods}

Study Site. Hutan Lipur Soga Perdana (N $01^{\circ} 50^{\prime} .899^{\prime \prime}$ E $\left.102^{\circ} 57^{\prime} .627^{\prime \prime}\right)$ is an amenity forest located at the nearest town of Batu Pahat through Jalan Kluang-Batu Pahat (Fig. 1).

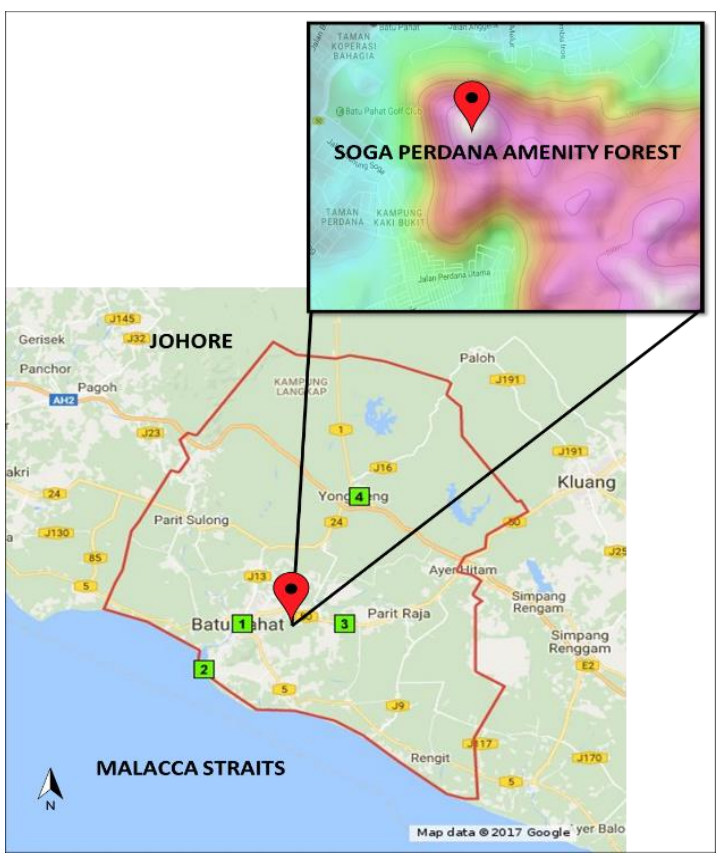

Fig. 1 Map of Johore showing location of Batu Pahat and study areas of Hutan Lipur Soga Perdana (Unscaled).

Being part of Hutan Lipur Soga Perdana it covers an area of $1,020.34$ hectares which is categorized as a highland dipterocarp forest with elevation over 200 meter a.s.l. Sampling was conducted in Hutan Lipur Soga Perdana on December 22-24, 2016 and January 9-11, 2017 for a total of six sampling days. The water bodies can be categorized into two which are slow flowing water of small streams with water depth not more than 0.5 meter (Fig. 2a) and the stagnant water with depth more than 0.5 meter (Fig. 2b).

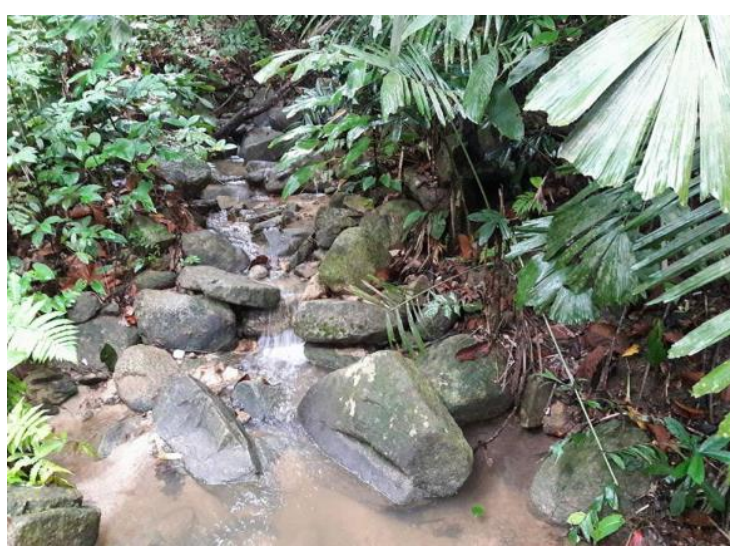

Fig. 2a Sampling station with dense tree and bush vegetation with small amount of running water.

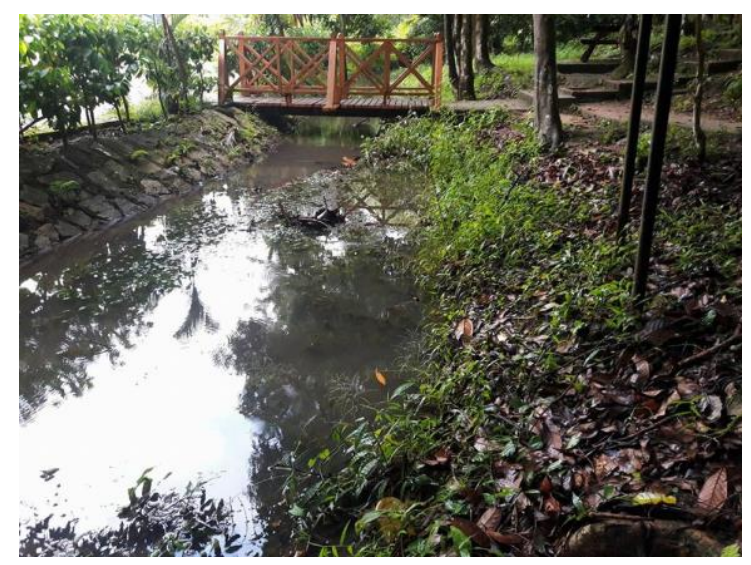

Fig. 2b Sampling station with large open areas of lentic with emergent vegetation along the water border.

Sampling and Identification. Samples were collected from temporary and permanent water bodies located nearby the study areas using sweep net by moving along $1 \mathrm{~km}$ of line transect. This method has been widely used for quantitative sampling of odonates [14].

The sampling locations were divided into 21 sampling stations nearest to the water bodies with distance of 50 meter between each sampling point (Fig. 3). The abundance is determined by the number of individuals of each species encountered during a total of six days of sampling period.

All specimens caught were placed in the temporary triangle envelopes with the wings 
folded together above the body and relevant information was written on the label outside of the envelope and specimens were identified up to species level by using identification guide book [3]. Some specimens that are unable to identified using the guide book will be referred to an expert for the species confirmation. Specimens were well preserved in the envelopes with treatment of acetone and dried in silica gel. All of the collected specimens are in the possession of first author.

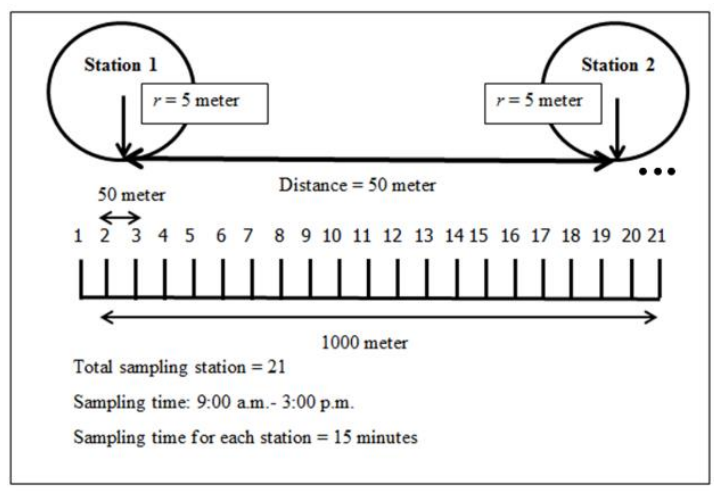

Fig. 3 A schematic drawing of sampling station using a $1 \mathrm{~km}$ line transect.

Data Analysis. Diversity indices Shannon's diversity index, $\mathrm{H}^{\prime}$ and Simpson Evenness Index (1-D) were calculated using software PAST v2.17. The most and least abundant species in each spot and in the area were calculated by using the abundance formula.

\section{Results}

Species Composition. A total of 22 species of odonates representing 17 genera from seven families were recorded (see Table 1). The families were: Devadattidae, Coenagrionidae, Euphaeidae, Platycnemididae, Platystictidae, Gomphidae and Libellulidae. A total of 13 Anisoptera (dragonfly) species and 9 Zygoptera (damselfly) species were collected and recorded throughout the surveys. Libellulidae was the most dominant, with 12 species, followed by Coenagrionidae and Platycnemididae (3 species) while Euphaeidae, Gomphidae, Platystictidae and Devadattidae were represented by only one species respectively. The most dominant genera were Orthetrum with 4 species collected (O. sabina, $O$. chrysis, O. testaceum and O. glaucum) following by Prodasineura and Trithemis with
2 species each ( $P$. notostigma, P.humeralis, $T$. aurora and $T$. festiva). The most abundant species were Tyriobapta torrida (Libellulidae) $(\Delta=20)$, following by Prodasineura notostigma (Platycnemididae) $(\Delta=16)$, Neurothemis fluctuans (Libellulidae) $(\Delta=15)$, Drepanosticta fontinalis (Platystictidae) $(\Delta=$ 13) and Orthetrum tetraceum (Libellulidae) $(\Delta=11)$. Table 1 shows the list of species with respective number of individuals of odonates recorded at Hutan Lipur Soga Perdana arranged in a taxonomic system.

Diversity Indices. During the study, Shannon and Simpson diversity indices were calculated as a measure of diversity of Hutan Lipur Soga Perdana (see Table 2).

\section{Discussion}

Species Richness. From the suborder Anisoptera, family Libellulidae is the dominant represented by 12 species followed by Gomphidae with one species. While in suborder Zygoptera, family Coenagrionidae and Platycnemididae is the dominant represented by 3 species respectively, followed by Devadattidae, Platystictidae, Platycnemididae and Euphaeidae with one species respectively. The two largest well known families that are commonly recorded are Libellulidae and Coenagrionidae and mostly favour open habitats of stagnant waters [15]. Most of Libellulidae usually breeds in lentic habitats or stagnant water although there are some exception for stream dwellers species [16]. These two families include species with greatest migratory capacity including those with distributions spanning more than one continent [2].

Several studies reported that Libellulidae and Coenagrionidae are top predators in both aquatic and terrestrial food chain and these family are usually aggressively consuming almost all flying insects [17,18]. Another study on the diversity, distribution and species composition of odonates in buffer areas in India found that Libellulidae was the most highest number of species that made up 53\% of the samplings followed by Coenagrionidae with $19 \%$ as the second largest representative [19]. Previous work by several authors noted that Libellulidae is most dominant family and their distribution is widespread locally and globally $[6,19,20,21,22,23]$. 
Abundance. From this study it shows that Tyriobapta torrida comprising of $15.9 \%$ of total abundance, were found perched with wing flat on tree trunks, mostly in station 3 (N 01 ${ }^{\circ} 50^{\prime} .938^{\prime \prime}$ E $\left.102^{\circ} 57^{\prime} .600^{\prime \prime}\right)$ where the habitat is an open area of stagnant waters that are mostly exposed to the sunlight and bordered by a varieties vegetation with an elevation ranging from 43 to 53 meter. Tyriobapta torrida usually found hovering at forest swamps with elevation ranging from 0 to 600 meter and both sexes commonly perching flat on tree trunks along the forest paths [3].

Prodasineura notostigma is the second abundant species (12.7\%) and was commonly found along the slow flowing shallow river in forested area that is slightly shaded with some sunny spot and research done stated that Prodasineura notostigma commonly found at forest streams with elevation ranging from 0 to 1000 meter [3].

Neurothemis fluctuans is one of the most abundant species found hovering at station 3 where the habitat is an open area that is totally exposed to sunlight. Neurothemis fluctuans is a widespread species and the most common found in Malaysia dominating the habitats of open ponds [24]. Neurothemis fluctuans is a very common species found around lakes, drains, marshes and paddy field and the larvae have the ability to withstand high water temperature in shallow pools [3].

The ability to survive in the existing environmental conditions is the reason for a high number of individuals in common and widespread species compared to rare species [25]. Most of the species with high abundance were found at open areas (Station 3) and these support the fact that the amount of solar is

Table 1 List of odonates recorded at Hutan Lipur Soga Perdana, Batu Pahat, Johor, Malaysia.

\begin{tabular}{|c|c|c|c|}
\hline No. & $\begin{array}{l}\text { Family } \\
\text { Species }\end{array}$ & No. of Individuals & Abundance $(\%)$ \\
\hline & Devadattidae & & \\
\hline \multirow[t]{2}{*}{1.} & Devadatta argyoides Selys 1859 & 4 & 3.2 \\
\hline & Euphaeidae & & \\
\hline \multirow[t]{2}{*}{2.} & Euphaea impar Selys 1859 & 6 & 4.8 \\
\hline & Coenagrionidae & & \\
\hline 3. & Archibasis viola Lieftinck 1949 & 2 & 1.6 \\
\hline 4. & Ceriagrion cerinorubellum Brauer 1865 & 3 & 2.4 \\
\hline \multirow[t]{2}{*}{5.} & Pseudagrion microcephallum Rambur 1842 & 3 & 2.4 \\
\hline & Platycnemididae & & \\
\hline 6. & Copera marginipes Rambur 1842 & 1 & 0.8 \\
\hline 7. & Prodasineura notostigma Selys 1860 & 16 & 12.7 \\
\hline \multirow[t]{2}{*}{8.} & Prodasineura humeralis Selys 1860 & 1 & 0.8 \\
\hline & Platystictidae & & \\
\hline \multirow[t]{2}{*}{9.} & Drepanosticta fontinalis Lieftinck 1937 & 13 & 10.3 \\
\hline & Gomphidae & & \\
\hline \multirow[t]{2}{*}{10.} & Ictinogomphus decoratus Selys 1858 & 1 & 0.8 \\
\hline & Libellulidae & & \\
\hline 11. & Brachydiplex chalybea Brauer 1868 & 1 & 0.8 \\
\hline 12. & Crocothemis servilia Drury 1770 & 1 & 0.8 \\
\hline 13. & Neurothemis fluctuans Fabricius 1793 & 15 & 11.9 \\
\hline 14. & Orthetrum chrysis Selys 1891 & 9 & 7.1 \\
\hline 15. & Orthetrum glaucum Brauer 1865 & 1 & 0.8 \\
\hline 16. & Orthetrum sabina Drury 1770 & 8 & 6.3 \\
\hline 17. & Orthetrum tetraceum Burmeister 1839 & 11 & 8.7 \\
\hline 18. & Pantala flavescens Fabricius 1798 & 1 & 0.8 \\
\hline 19. & Pseudothemis jorina FÖrster 1904 & 2 & 1.6 \\
\hline 20. & Trithemis aurora Burmeister 1839 & 6 & 4.8 \\
\hline 21. & Trithemis festiva Rambur 1842 & 1 & 0.8 \\
\hline 22. & Tyriobapta torrida Kirby 1889 & 20 & 15.9 \\
\hline
\end{tabular}


directly proportional with the diversity of odonates habitat [26].

The least abundant species were Prodasineura humeralis, Ictinogomphus decoratus, Copera maginipes, Orthetrum glaucum, Trithemis festiva, Pantala flavescens, Brachydiplex chalybea and Crocothemis servilia which represented by single individual $(0.8 \%)$ respectively. However, as stated in [3] all these species were common and widespread species. Ictinogomphus decoratus was the only species of Gomphidae collected in this study. Gomphidae is one of the family that are difficult to collect as they spend a little time at waterside and seldom perch and this is the reason for low abundance of Gomphidae collected in this study [2].

The migratory species such as Panthala flavescens are worldwide in tropics and commonly found almost everywhere in open country, mainly breeds in lentic or slow flowing water and adults commonly venture far from water over the canopy, often present in large swarms [3]. This migratory species were only recorded at open area and flying high over the canopy making it difficult for collecting the specimen. The area with high or moderate shade cover will affect the abundance of species, for example the Trithemis as they exhibited shade avoidance behavior $[27,28]$.

High percentage of shade limits prey availability, mate attraction, hunting effectiveness, habitat selection and thermoregulation. Hutan Lipur Soga Perdana (HLSP) is mostly covered an area with high percentage of canopy coverage and shade cover causing the limited distribution of Trithemis $s p$. and the only region the specimen collected was in an open area (Station 3). Brachydiplex chalybea and Crocothemis servilia were also collected in an open area of lentic waters (Station 3) and both of these species are indicator for disturbed habitat [3]. Station 3 is an area that are commonly used for recreational activities and for relaxation and located near to the human settlement areas causing the anthropogenic impact on the aquatic environments in these area and disturbance towards the aquatic environments and its surrounding.

The protection of the species that live within urban wildlife habitats or green lung is depending on the size of urban green spaces
[29]. Therefore, it is important to make sure that the area of green spaces remains 'untouchable' in order to ensure the conservation efforts of green lung as they play important roles in ecological functions and thus increase the quality of life for urban populations.

Endemicity. There is one endemic species recorded from this sampling, Drepanosticta fontinalis (Fig. 4). Drepanosticta fontinalis was found to be abundant $(10.3 \%)$ at closed canopy region with high shade and small streams with slow flowing water with bordered vegetation surrounding the aquatic habitat. Drepanosticta fontinalis is an endemic species of Peninsular Malaysia and the commonest member of genus Drepanosticta which commonly found at springs and small streams in primary forest with elevation ranging from 0 to 900 meter [3].

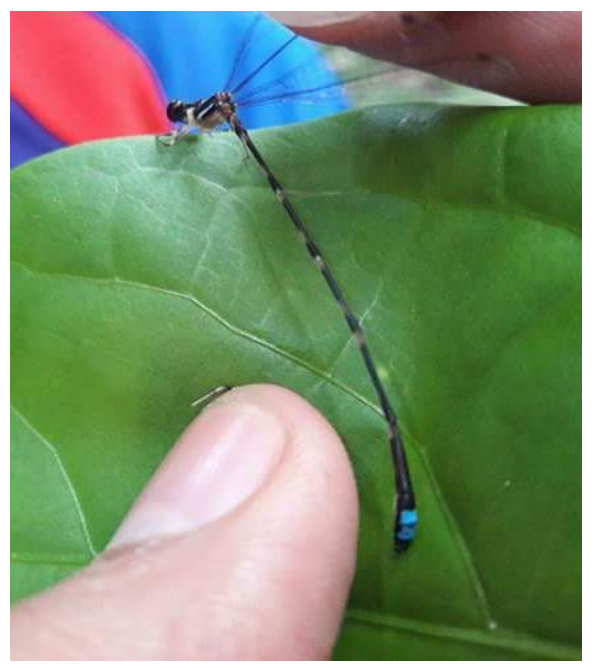

Fig. 4 An endemic species of Peninsular Malaysia, Drepanosticta fontinalis in Hutan Lipur Soga Perdana, Batu Pahat, Johor.

According to assessment in IUCN Red List of Threatened Species 2009 stated that Drepanosticta fontinalis is categorized as Near Threatened and more data is needed on this species. There are only seven published records for $D$. fontinalis which are from Pahang (Tioman Island), Bukit Mertajam in Penang, Bukit Larut (formerly Maxwell Hill) in Perak, Gunung Jerai in Kedah, Panti Forest Reserve in Johor and most recently, Angsi Forest Reserve in Negeri Sembilan [30]. 
Diversity Indices. The higher the value of Shannon-Wiener Diversity Index (H'), the higher the diversity of the species in the area and as the number of species in the area increase, the index value will also increase [31]. The value of Shannon-Wiener Diversity Index calculated is 2.63 (see Table 2). A value that range from 1.5 to 3.5 is considered to have a moderate diversity [32].

Table 2 Diversity Indices of Odonates at Hutan Lipur Soga Perdana

\begin{tabular}{|c|c|}
\hline Diversity Index & Index Value \\
\hline $\begin{array}{c}\text { Shannon Wiener } \\
\text { Species Diversity } \\
\text { Index (H') }\end{array}$ & 2.63 \\
\hline $\begin{array}{c}\text { Simpson Index } \\
\text { (1-D) }\end{array}$ & 0.91 \\
\hline
\end{tabular}

The reason for higher species diversity is commonly related to diversification of ecosystems [33] and presence of various microhabitats [21]. Hutan Lipur Soga Perdana is located nearby human settlement areas and causing the habitat to be exposed toward human disturbances that could affect the diversity of odonates found within these areas.

The value of Simpson Evenness Index is 0.91 which indicating a high evenness in distribution of odonates at Hutan Lipur Soga Perdana as the values are closer to one. The evenness value that closer to one indicates even distribution while a value closer to zero indicating that there is a dominat species [34].

The diversity of an area increases as the richness and evenness within the community increase [35]. The quality of green spaces can be indicated by the richness and density of species found within the areas and these statement can be proven by several studies that the urban areas record lower species richness compared to suburban areas [36,37].

Urbanization have a direct impacts on wildlife biodiversity as their natural habitas are being replaced with development, both housing and industrial and these projects will continuously grow in coming years. Therefore, it is important to make sure that the green lung is being protected from facing these effects of urbanization.

Conservation. Batu Pahat is one of the urban areas in Malaysia that are continuously developing and have a lot of ongoing industrial development. It is very important to minimize the impact of these development towards ecosystems in general, especially Hutan Lipur Soga Perdana as a green lung of Batu Pahat. Conservation and establishment of protected areas are key to secure the rainforests for the long-term benefits they can provide mankind. From the results, it can be concluded that Hutan Lipur Soga Perdana have a moderate diversity of odonates. However, this forest have recorded one endemic species, Drepanosticta fontinalis that indicate an excellent habitat quality.

Habitat destruction and water pollution are the main problem for conservation of the species [38]. Increase in the rate of urbanization will also increase the anthropogenic activities that causes water pollution and stress towards the green lung in the city [39] and thus causing a direct impacts towards odonate populations from these habitats. Odonates spend most of their life in aquatic habitats, nymphs are fully aquatic and any changes towards the water bodies will affect their survivality as most of the species required a good water quality to thrive and survive. Therefore, it is important to conserve these habitats and avoid pollution from continuously happening at this site especially the buffer area which is open to public access mainly for recreational activity.

The invertebrates, specifically insects is a group of organisms that has the highest risk of extinction due to the loss of biodiversity [40]. Odonates is one of the insect groups that are commonly used in the assessment of water quality and habitat conditions and act as a key factor in the conservation actions. This research is part of an effort to prepare a baseline data for diversity and distribution of odonates at major water bodies in Johor. The result of this research is expected to be the first step in the conservation of odonates and their habitats by prioritizing conservation areas in Johor. Therefore, much more work and intensive sampling are needed in both protected and unprotected areas to collect more data on the diversity and distribution of odonates throughout the region.

\section{Conclusions}

Increase in urbanization will resulted in reduction of green spaces and the main causes are due to the increase in demand for building and housing developments in urban areas. 
Therefore, a proper management and planning by government are needed to overcome these problems in spite of the fact that knowledge and expertise on these field are still lacking [41].

Through this six days of sampling at Hutan Lipur Soga Perdana, a total of 22 species of odonates were collected. Comparatively this number is low because as a forest reserve, this ecosystem would surely support many more species and of higher abundance. It is recommended that further samplings be made for odonates at Hutan Lipur Soga Perdana covering longer period of time. There are few research that study on the impact of urbanization towards biodiversity $[29,36,39,41]$ which focused on avifauna as bioindicator of the green spaces. Insects, another groups of important biological indicator of green spaces including odonates should be highlighted and this research is part of an effort towards conservation of biodiversity of the green lung.

\section{Acknowledgements}

We would like to thank the Johor State Forestry Department for their permission to conduct this research in Hutan Lipur Soga Perdana. Special thanks to Dr. Choong C.Y. (UKM) for the help in identification and confirmation of several species and to researcher's team for their continuous support in writing and throughout the sampling period. The research was supported by UTHM Research Contract Grant (U393) received by the second author.

\section{References}

[1] World Heritage Encyclopedia. (2017). Batu Pahat. Retrieved on 9 August 2017, fromhttp://worldheritage.org/articles/eng/ Batu_Pahat

[2] Kalkman, V. J., Clausnitzer, V., Dijkstra, K.D.B., Orr, A.g., Paulson, D.R., \& Van Tol, J. (2008). Global Diversity of Dragonflies (Odonata) in Freshwater. Hydrobiologia, Vol. 595. No.1 pp. 351363.

[3] Orr, A.G. (2005). A Pocket Guide to Dragonflies of Peninsular Malaysia and Singapore. Natural History Publications (Borneo), Sabah, Malaysia.
[4] Choong, C.Y., Orr, A.G. \& Dow, R.A. (2008b). Checklist of Dragonflies of UKM campus, including Bangi Forest Reserve, Bangi, Selangor, Malaysia. Agrion, Vol. 12. No. 1 pp. 40.

[5] Dow, R.A., Choong, C. Y. \& NG, Y.F. (2010). A Review of the Genus Amphicnemis in Peninsular Malaysia and Singapore with Descriptions of Two New Species (Odonata: Zygoptera: Coenagrionidae). Zootaxa, Vol. 2605. No. 1 pp. 45-55.

[6] Izzat-Husna, M. \& Ahmad, A.B. (2014). Odonata (Class Insecta) of Sungkai Wildlife Reserve, Perak, Malaysia. Journal of Wildlife and parks, Vol. 29. pp. 23-30.

[7] Ramesh, T., Hussain, K.J., Satpathy, K.K, Selvanayagam, M. \& Prasad, M.V.R. (2010). Diversity, Distribution and Species Composition of Ants Fauna at Department of Atomic Energy (DAE) Campus Kalpakkam, South India.

[8] Orr, A.G. (2003). A Guide to the Dragonfly of Borneo: Their Identification \& Biology. Kota Kinabalu, Sabah. Natural History Publication (Borneo).

[9] Watanabe, M., Matsuoka, M. \& Taguchi, M. (2004). Habitat Selection and Population Parameters of Sympetrum Infuscatum (Selys) during Sexual Mature Stages in a Cool Temperate Zone of Japan (Anisoptera: Libellulidae). Odonatologica, Vol. 33. pp. 169-179.

[10] Nelson, B., Ronayne, C., \& Thompson, R. (2011). Ireland Red List No. 6: Damselflies and Dragonflies (Odonata). Dublin: National Parks and Wildlife Service.

[11] Wahizatul-Afzan, A., Julia, J. \& Amirrudin, A. (2006). Diversity and Distribution of Dragonflies (Insecta: Odonata) in Sekayu Recreational Forest, Terengganu. Journal of Sustainability Science and Management, Vol. 192. pp. 97-106.

[12] Dijkstra, K.D.B. \& Clausnitzer, V. (2006). Thoughts from Africa: How Can Forest Influence Species Composition, Diversity and Speciation in Tropical Odonata. In: Cordero Rivera, A. (Ed.). Forests and dragonflies. Pensoft Publishers, pp.127151.

[13] Orr, A.G. (2006). Odonata in Bornean Tropical Rainforesr Formations: Diversity, Endemicity and Implications for 
Conservation Management. In: Cordero Rivera, A. (Ed.). Forest and Dragonflies. Pensoft Publisher, pp. 51-78.

[14] Baruah, C. \& Saikia, P.K. (2015). Abundance and Diversity of Odonates in Different Habitats of Barpeta District, Assam, India, International Research Journal of Biological Sciences, Vol. 4. No. 9 pp. 17-27.

[15] Kaize, J. \& Kalkman, V.J. (2011). Records of Dragonflies (Odonata) from Kabupateb Asmat and Kabupaten Mappi (Papua, Indonesia). Suara Serangga Papua, Vol. 5. No.1 pp. 99-107.

[16] Kiany, M. \& Minaei, K. (2009). The Dragonfly Family Libellulidae (Insecta: Odonata: Anisoptera) of Shiraz and its Vicinity, Iran. Agricultural Research, Vol. 27/28. No. 1 pp. 65-78.

[17] Kandibane, M., Raguraman, S. \& Ganapathy, N. (2005). Relative Abudance and Diversity of Odonata in an Irrigated Rice Field of Madurai, Tamil Nadu. Zoo's Print Journal, Vol. 20. No.11 pp. 20512052.

[18] Sharma, J. G. \& Joshi, P.C. (2007). Diversity of Odonata Insecta) from Dholbaha Dam, District Hoshiapur, Punjab Shivalik, India. Journal Asia Pacific Entomology, Vol. 10. No. 2 pp. 177-180.

[19] Das, S.K., Ahmed, R.A., Sajan, S.K., Dash, N., Sahoo, P., Mohanta, P., Sahu, H.K., Rout, S.D. \& Dutta, S.K. (2012). Diversity, Distribution and Species Composition of Odonates in Buffer Areas of Similipal Tiger Reserve, Eastern Ghat, India. Academic Journal Entomology, Vol. 5. pp. 54-61.

[20] Dalzochio, M.S., Costa, J.M. \& Uchoa, M.A. (2011). Diversity of Odonata (Insecta) in Lotic Systems from Serra de Bodoquena, Mato Grosso do Sul State, Brazil. Revista Brasileira de Entomologia, Vol. 55. No. 1 pp. 88-94.

[21] Mamat, N., Norma-Rashid, Y. \& Mohamed, Z. (2012). Diversity and Habitat Preferences of Dragonflies (Order: Odonata) in Selangor, Peninsular Malaysia. Wulfenia Journal, Vol. 19. No.11 pp. 1-20.

[22] Mapi-Ot, E.F., Taotao, A.U., Nuneza, O.M. \& Villanueva, R.J.T. (2013). Species Diversity of Adult Odonata in Selected Areas from Misamis Occidental Province,
Phillipines. AACL Bioflux, Vol. 6. No. 4 pp. 421-432.

[23] Basumatary, p., Adhikary, D., Daimary, M., Basumatary, N. \& Daimary, A. (2015). A Preliminary Study on the Diversity of Odonata in Bodoland University and its Vicinity, Assam, India. International Journal of Scientific and Research Publications, Vol. 5. No.6, pp. 18.

[24] Norma-Rashid, Y. (2010). Dragonflies (Odonata) of Coastal Bachok, Kelantan and Promoting Common Names. Malaysian Journal of Science, Vol. 28. (Special Issue), pp. 73-79.

[25] Shelton, M.D. \& Edward, C.R. (1983). Effect of Weeds on the Diversity and Abundance if Insects in Soybeans. Environmental Entomology, Vol. 1. pp. 296-299.

[26] Samways, M.J. (2006). Threat Levels to Odonate Assemblages from Invasive Alien Tree Canopies. In: Cordero Rivera, A. Forest and Dragonflies. Pensoft Publisher, pp. 209-224.

[27] Corbet, P.S. (1999). Dragonflies: Behaviour and Ecology of Odonata. Colchester: UK, Harley Books.

[28] Remsburg, A.J., Olson, A.C. \& Samways, M.J. (2008). Shade Alone Reduces Adult Dragonfly (Odonata: Libellulidae) Abundance. Journal of Insect Behavior, Vol. 21. No.6 pp. 460-468.

[29] Karuppannan, S., Baharuddin, Z.M., Sivam, A. \& Daniels, C.B. (2014). Urban Green Spaces and Urban Biodiversity: Kuala Lumpur, Malaysia. Journal of Sustainable Development, Vol. 7. No.1 pp. 1-14.

[30] Dow, R.A. (2009). Drepanosticta fontinalis. The IUCN Red List of Threatened Species 2009.

[31] Rosenzweig, M.L. (1995). Species Diversity in Space and Time. Cambridge: Cambridge University Press.

[32] Molles, M.C.JR. (1999). Ecology, Concepts and Applications. International Edition. Boston, USA. Mc Graw Hill Companies Inc.

[33] MacArthur, R.H. (1965). Patterns of Species Diversity. Biological Reviews, Vol. 40. No. 4 pp. 510-533.

[34] Cerda, X., Angulo, E., CCaut, S. \& Courchamp, F. (2011). Ant Community Structure on a Small Pacific Island: Only 
One Native Species Living with the Invaders. Biological Invasions, Vol. 14. No. 1 pp. 323-339.

[35] Magurran, A.E. (2004). Measuring Biological Diversity. Oxford: Blackwell Science.

[36] Chase, J.F. \& Walsh, J.J. (2006). Urban Effects on Native Avifauna: A Review. Landscape and urban Planning, Vol. 74. No.1 pp. 46-69.

[37] Savard Jean-Pierre, L., Clergeau, P. \& Mennechez, G. (2000). Biodiversity Concepts and Urban Ecosystems, Landscape and Urban Planning, Vol. 48. No. 3 pp. 131-142.

[38] Rivera, A.C. (2000). Distribution, Habitat Requirements and Conservation of Macromia Splendens Pictet (Odonata: Corduliidae) in Galicia (NW Spain). International Journal of Odonatology, Vol. 3. No. 1 pp. 73-83.

[39] Kuruvilla, K. (2014). Avian Diversity of Vadakkechira Area, A Green Lung of Thrissur. IOSR Journal of Environmental Science, Toxicology and Food Technology, Vol. 8. No. 7 pp. 55-60.

[40] Thomas, J.A., Telfer, M.G., Roy, D.B., Preston, C.D., Greenwood, J.J.D., Asher, J., Fox, R., Clarke, R.T. \& Lawton, J.H. (2004). Comparative Losses Of British Butterflies, Birds And Plants And The Global Extinction Crisis. Science, Vol. 303. pp. 1879-1881.

[41] Baharuddin, Z.M., Sivam, A., Karuppannan, S. \& Daniels, C. (2009). Role and Perception of Green Spaces: Attitudes Towards Urban Wildlife in Kuala Lumpur and Adelaide. International Symposium on Construction in Developing Economies: Commonalities Among Diversities, pp. 5-7. 